\title{
Integrating Service-Learning Pedagogy: A Faculty Reflective Process
}

\author{
Carmen Carracelas-J uncal, PhD \\ Assistant Professor, Department of Foreign Languages and Literature \\ University of Southern Mississippi \\ Jenny Bossaller, PhD \\ Assistant Professor, School of Library and Information Science \\ University of Southern Mississippi \\ Gallayanee Yaoyuneyong, PhD \\ Assistant Professor, Department of Marketing and Fashion Merchandising \\ University of Southern Mississippi
}

\begin{abstract}
Research on service-learning has focused mainly on student outcomes. However, this study addresses the transformative change that three faculty members from different disciplines experienced during a semester-long fellowship on servicelearning as a pedagogical method. Through their personal reflections, the authors show how service-learning and the scholarship of teaching were intertwined as they engaged in course redesign. This experience went beyond creating an academic service-learning course to transforming the teachers into reflective practitioners actively engaged in systematically improving their teaching practice.
\end{abstract}

\section{Introduction}

For the last two decades, there has been a movement in academia to provide students with a richer academic environment that includes real-world experience. More and more professors are turning to service-learning pedagogy to achieve this goal. This article documents the first steps that three faculty members, each from different disciplines, went through to learn about service-learning and to design their first service-learning course. We analyze the transformative change that we experienced during a semester-long fellowship focused on service-learning as a pedagogical method and its application in the classroom. First, however, it is important to define what service-learning is-and is not-before describing how it can lead faculty to the scholarship of teaching.

\section{What is Service-Learning?}

Service-learning is a model of education which combines traditional classroom learning with experiences that engage the student with the world outside of the university. The Community College National Center for Community Engagement defines service-learning as "a teaching method which combines community service with academic instruction as it focuses on critical, reflective thinking and civic responsibility" (Campus Compact, 2003, p. 9). The service component often takes place through community partnerships with nonprofit agencies. Service-learning students

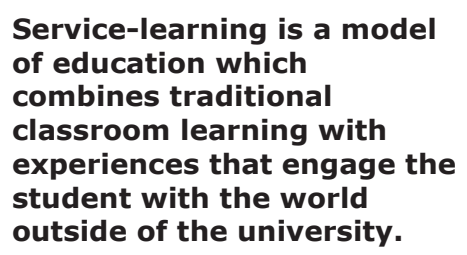

work with community organizations and then engage in reflective activities, such as journaling and self-critiques couched within academic papers, which provide them with another lens through which to view their civic engagement as a part of the learning process. This three-pronged teaching pedagogy (traditional classroom learning, service, and reflection) is often viewed as a transformational educational experience, with each component enhancing the other. 
It is important to emphasize that service-learning is not merely volunteering; it requires the same rigorous academic component as traditional classroom learning. As Howard (1998) explains, "The service and the learning are reciprocally related; the service experiences inform and transform the academic learning, and the academic learning informs and transforms the service experience" (p. 21). Furco (1996) emphasizes that there must be a finely integrated "balance between learning goals and service outcomes" (p. 3). Service-learning not only helps students gain a deeper understanding of their subject matter but also increases their civic awareness and engagement: "Service-learning is a method through which citizenship, academic subjects, skills, and values are taught. It involves active learning-drawing lessons from the experience of performing service work" (Campus Compact, 2003, p. 7). Additionally, service-learning has been found to increase student retention, sense of inclusion in the campus community, and student-faculty relations by breaking down some of the barriers that exist in the traditional classroom environment (Eyler, Giles, Stenson \& Grey, 2003, p. 17).

\section{What Service-Learning is Not}

Howard (1998) points out that service-learning "is not about the addition of service to learning, but rather the integration of service with learning" (p. 21). Service-learning is not to be confused with internships, which put the student in a mock-work, or pre-work situation, or with community service. It must combine academic learning with service, thus the hyphenated "service-learning"1 (Eyler and Giles, 1999, p. 2-5). As Bringle and Hatcher (1996) note:

"Unlike practica and internships, the experiential activity in a service learning course is not necessarily skill-based within the context of professional education" (p. 222). In other words, the purpose of service-learning assignments is not just to improve the technical, discipline-specific effectiveness of student skills. It is also "to gain...a broader appreciation of the discipline, and an enhanced sense of civic responsibility" (p. 222). In this regard, service-learning shifts attention away from an exclusive preoccupation with education as private gain and seeks to balance that concern with a focus on the common good (Zlotkowski, 1999, p. 102).

\section{What is the Importance of Service-Learning?}

Service-learning has been shown to provide distinct benefits for students. As a teaching methodology, service-learning, by its very nature, can accommodate different types of learning styles. Zlotkowski (1999) pointed out that "by linking theory and practice, reflection and experimentation, as described by Kolb (1984), service-learning opens up the learning process to accommodate a much wider variety of student learning styles than has traditionally been the case" (p. 107). Service-learning helps students develop critical thinking and problem solving skills by encouraging them to apply the theory learned in the classroom to real-life situations. Dewey (1916) wrote extensively about the importance of experiential learning: " $[A] n$ ounce of experience is better than a ton of theory because it is only in experience that any theory has vital and verifiable experience" (p. 144).

Service-learning also seems to help bridge "the gap between traditional curricular content and society's needs for new competencies for workers and citizens," one of the criticisms against higher education. "The emphasis in servicelearning on applying knowledge to community problems and the reciprocal application of community experience to the development of knowledge meets many of the concerns about this lack of connectedness" (Eyler \& Giles, 1999, pp. 12-13). Zlotkowski (1999) concurs,

If, (...), Barr and Tagg (1995) are correct and higher education is in the midst of a major conceptual shift from education as a 
system for delivering instruction to education as a system for producing learning ( $p .13$ ), service learning's significance only increases. This is a function not only of the way in which it works but also of what it seeks to accomplish. (p. 107)

Service-learning is also a teaching pedagogy that requires a deep involvement and commitment to the scholarship of teaching.

\section{Scholarly Teaching and Service-Learning}

It is important to emphasize that service-learning is not simply a learning tool; service-learning is a teaching methodology (Howard, 1998, p. 21). Schön (1995) proposed that "if teaching is to be seen as a form of scholarship, then the practice of teaching must be seen as giving a rise to new knowledge" (p. 31). In other words, teaching has to be approached as research. According to Trigwell, Martin, Benjamin, \& Prosser (2000), Boyer (1990) argued that rather than separating teaching and research, the two should be joined together in overlapping areas of scholarship, including discovery, integration, application, and teaching ( $p$. 155). Shulman (1993) stated that there are three elements in teaching: Communication, scholarship, and peer review; scholarly communication happens when each member of a particular academic community actively shares findings-discussing, critiquing, exchanging, evaluating, and building on each other's works. Trigwell et al. (2000) suggested that the purpose of scholarly teaching is "to make transparent how we have made learning possible...This involves reflection, inquiry, evaluation, documentation and communication" (p. 156). All of these elements are integral to service-learning pedagogy. In their research on the scholarship of teaching, Trigwell et al. (2000) developed a multi-dimensional model of scholarship of teaching (see Table 1$)^{2}$.

Table 1: Multi-dimensional model of scholarship of teaching

\begin{tabular}{|c|c|c|c|c|}
\hline & $\begin{array}{c}\begin{array}{c}\text { Informed } \\
\text { dimension }\end{array} \\
\end{array}$ & $\begin{array}{l}\text { Reflection } \\
\text { dimension }\end{array}$ & $\begin{array}{c}\text { Communication } \\
\text { dimension }\end{array}$ & $\begin{array}{c}\text { Conception } \\
\text { dimension }\end{array}$ \\
\hline Level 1 & $\begin{array}{l}\text { Uses informal } \\
\text { theories of } \\
\text { teaching and } \\
\text { learning }\end{array}$ & $\begin{array}{l}\text { Effectively none } \\
\text { or unfocused } \\
\text { reflection }\end{array}$ & None & $\begin{array}{l}\text { Sees teaching in } \\
\text { a teacher- } \\
\text { focused way }\end{array}$ \\
\hline Level 2 & $\begin{array}{l}\text { Engages with the } \\
\text { literature of } \\
\text { teaching and } \\
\text { learning generally }\end{array}$ & None & $\begin{array}{l}\text { Communicates with } \\
\text { department/faculty } \\
\text { peer (tea room } \\
\text { conversation, } \\
\text { department } \\
\text { seminars) }\end{array}$ & None \\
\hline Level 3 & $\begin{array}{l}\text { Engages with the } \\
\text { literature, } \\
\text { particularly the } \\
\text { discipline literature }\end{array}$ & \begin{tabular}{|l|} 
Reflection-in- \\
action
\end{tabular} & $\begin{array}{l}\text { Reports work at } \\
\text { local and national } \\
\text { conferences }\end{array}$ & None \\
\hline Level 4 & $\begin{array}{l}\text { Conducts action } \\
\text { research, has } \\
\text { synoptic, and } \\
\text { pedagogic content } \\
\text { knowledge }\end{array}$ & $\begin{array}{l}\text { Reflection focused } \\
\text { on asking what do } \\
\text { I need to know } \\
\text { about X here, and } \\
\text { how will I find out } \\
\text { about it? }\end{array}$ & $\begin{array}{l}\text { Published in } \\
\text { international } \\
\text { scholarship journals }\end{array}$ & $\begin{array}{l}\text { See teaching in a } \\
\text { student-focused } \\
\text { way }\end{array}$ \\
\hline
\end{tabular}

According to their research, Level 4 describes those teachers who are "more likely to be engaging in scholarship of teaching" (Trigwell et al., 2000, p. 164). These are teachers who: 
seek to understand teaching by consulting and using the literature on teaching and learning, by investigating their own teaching, by reflecting on their teaching from the perspective of their intention in teaching while seeing it from the students' position, and by formally communicating their ideas and practice to their peers (p. 164).

Service-learning and the scholarship of teaching share the same aims. In our experience, integrating a service-learning component into our classes led us to demonstrate the four dimensions of Level 4 scholarship of teaching.

\section{Institutional Support for Faculty in Service-Learning}

Prior to an analysis of our experiences, it is necessary to point out the role of institutional support in implementing service-learning pedagogy. Zlotkowski (1999) identified two critical areas of institutional support. First, the institution must supply "a comprehensive faculty development effort to help those working in disciplinary areas across the academic spectrum to both understand and appropriate service learning on their own terms" (p. 100).

Second, it must include available structures to the faculty "that facilitate establishing and maintaining community partnerships... Successful programs almost always require the leadership of a professional staff person" (p.107). This type of institutional support is already in place at our university. At the University of Mississippi (USM), the Office of Community Service Learning is responsible for providing faculty with seminars to learn about service-learning pedagogy and building and maintaining ties with different organizations in the community.

While the University enjoys some status in the community, there is a certain amount of credibility that needs to be established in order to work as a volunteer. Thus, USM, through the Office of Community Service Learning, has developed partnerships with a number of community agencies, which facilitates the ability of the faculty to form a relationship with a partner. The Office of Community Service Learning also introduces interested faculty to community partners and maintains a list of agencies to contact for service projects. The University's support in this first crucial step toward establishing service-learning experiences in a course is important, especially in the case of junior faculty who are new to the area. One of the main advantages of having established community partnerships is that many of the agencies already understand the intentions and purpose of the faculty, making it easier for faculty to add a service-learning component to their classes.

\section{The Faculty Fellows Service-Learning Program}

At USM, the entire faculty is invited to submit applications ${ }^{3}$ to participate in a semester-long fellowship in order to learn about service-learning pedagogy, which involves either revising an existing course or creating a new one based on this teaching pedagogy. Each spring semester, six faculty members from different disciplines and areas of expertise are selected by the Faculty Fellows Advisory Council and the Office of Community Service Learning to participate in the ServiceLearning Faculty Fellows Program. The six faculty fellows are given a course release in order for them to be able to fully participate in the seminar. The seminar covers many different concepts related to service-learning and also gives participants the opportunity to hear reports from program alumni, view different syllabi from the University and from other institutions, discuss course requirements, and scrutinize some of the different teaching and learning approaches used in service-learning. The alumni's academic backgrounds are as varied as those of the participants' and include professors from disciplines such as business, history, math, English, sports management, and sociology. Discussing service-learning with alumni allows participants to engage in conversation with veterans regarding their different 
service-learning teaching approaches and to see the varied emphases given to the service-learning component of different courses. Other discussions broach subjects such as publishing opportunities and institutional support for classes. By opening the service-learning seminar to the entire faculty, the University shows its commitment to institutionalizing the service-learning program and, by extension, the scholarship of teaching.

During the course of the semester the enrolled faculty become students themselves, meeting weekly, discussing the literature, and leading discussions. They also must find and take part in their own service-learning project. The project helps them better understand what their students might experience during their own class, gives them realistic expectations for their course, and ultimately becomes a springboard for their own students' academically-integrated community involvement. During the weekly seminar meetings, the faculty fellows discuss the challenges and successes they are experiencing in their project. Participants are also advised to keep a journal about their service experience, and they are required to write two reflection papers. By sharing journal entries and reflections, the seminar becomes the space described by Shulman (1993): A place for the peer discussion, exchange, and critique which is needed to engage faculty in the scholarship of teaching.

\section{The Beginning and Purpose of this Study}

Our desire to critique and better understand the process through which our class and project developed; our reflections on our own learning through a real service-learning experience; and our goal of applying our own experiences to our teaching all led us to write about our experience. We have observed that most research on service-learning focuses on student learning outcomes ${ }^{4}$ and does not often address the processes and transformations that faculty undergo adopting a service-learning pedagogy. Although there have been some studies on the effects of servicelearning on faculty, those studies primarily commented on obstacles such as research expectations, lack of resources, and lack of faculty reward (Eyler et al., 2003, p. 18). We noted a need to document the process that faculty experience when they decide to adopt service-learning as a teaching methodology. When faculty decide to integrate a service-

When faculty decide to integrate a service-learning component in the classroom, they seek transformation and greater understanding in their students; yet, there is a lack of information in the published literature about how this very process also transforms and increases understanding within the faculty using the pedagogy ultimately leading faculty toward the scholarship of teaching. learning component in the classroom, they seek transformation and greater understanding in their students; yet, there is a lack of information in the published literature about how this very process also transforms and increases understanding within the faculty using the pedagogy, ultimately leading faculty toward the scholarship of teaching.

This article sheds light on this process of faculty transformation through an account of our experiences. We then compare our observations and experiences during the seminar to the existing literature on service-learning. This analysis contributes to a dialogue concerning faculty understanding of their own learning process and offers faculty readers an overview of the possible stages they will experience when introducing a service-learning component to their curriculum.

\section{Intertextual Analysis of Faculty Reflections on Service-Learning}

Reflection is a central element of both service-learning and the scholarship of teaching. Reflection allows the participant to analyze his or her own observations 
of the experience, as it unfolds. A longitudinal, or semester-long, reflection exercise can also engage the learner in what Braid (1996) termed experiential meaningspersonal narratives that "invoke both the sense of experience as a resource of accumulated wisdom and the sense of experience as an ongoing interpretive

\section{Reflection is a central element of both service- learning and the scholarship of teaching.}

process" (p. 6). Despite our very different disciplines, a clear process with three differentiated stages emerged from our narratives: Our initial enthusiasm and conviction, our encounter with reality, and our subsequent recommitment to service-learning. The following section contains excerpts from our individual writing that illustrate this process.

\section{Stage 1: I nitial enthusiasm and conviction.}

We came into the program with a great deal of enthusiasm; our application narratives demonstrate that we knew we wanted to integrate a service component into our courses, and had even conceptualized how to accomplish our goals of providing students with experience outside of the classroom walls. Self assurance and conviction permeate these application narratives, suggesting that we thought we had a clear sense of what service-learning would entail. The following excerpts illustrate our motivations for applying to the program, and what we expected to accomplish from our participation in the seminar.

Carmen Carracelas-J uncal (CCJ), first year Assistant Professor in the Department of Foreign Languages and Literatures

CCJ was drawn to the seminar as an avenue to promote social justice through literacy in the home language, specifically Spanish. Before coming to Hattiesburg, she worked with different elementary schools as Foreign Language Coordinator and in afterschool programs in her community introducing Spanish to children from K-6, but she did not have experience volunteering. She decided that it was time to get involved with the community on a personal and professional level, and she perceived that there was a need in the Spanish-speaking community in Hattiesburg, where not only she, but also her students, could be of service. As reflected in the following excerpt from her application essay, she planned on adding the service-learning component to the course: Introduction to Hispanic Literature.

There is a growing community of Spanish speakers in Hattiesburg with a significant number of children who will experience some level of language attrition in their mother tongue. There is a great need of literacy programs to ensure that these dual language learners acquire, and continue developing, reading and writing skills in their mother tongue. I would like to add a service learning component to my class so my students not only have the opportunity of exploring the fascinating world of literature in Spanish, but also of opening that world to the Spanish speaking children in the community by reading to them and with them in Spanish. This service component would be integrated in the course and would provide a two-way learning experience that would go beyond reading, to communicating and culturally understanding each other.

She had very clear goals that she wanted to attain through her participation in the seminar. On a personal level, she hoped that the seminar "[would] help me achieve one of my major goals for coming to USM: To serve the Spanish speaking community by helping its children appreciate and be proud of their language and their diverse cultures." On a professional level, she expected the seminar would put her in contact with the right community for her students to perform their service-learning component. She wrote, "this fellowship will allow me 
to polish this idea by figuring out how to organize the course and where the servicelearning component could be put into practice in the community." She saw the seminar as the necessary step toward getting in contact with the community.

After beginning the seminar, she reflected back on her decision to apply to the fellowship and became more aware of the possible outcomes of growth and enrichment for her students as they shared their skills with the community and reaped learning benefits in return. She wrote:

The reason I applied to be a participant in the service-learning seminar was two pronged. I wanted to find a way to help children not only maintain but develop their home language skills, and I wanted my students to see that majoring in Spanish is not just reading about the language or in the language, but that Spanish is a real vehicle for communication, beyond classmates and university contexts, and that the Spanish speaking world is made of many coexisting, complex and rich cultures, at times in conflict with each other.

Lenny Bossaller (JB), first year Assistant Professor in the School of Library and Information Science

J B applied to the fellowship in order to expose her students to a need and methods for literacy work in libraries, planning to design a course entitled Libraries and Literacy. Her dissertation work and previous volunteer experience involved adult new readers, which served as a backdrop for her service-learning goals:

The course which I intend to design will connect students at USM with some of the community organizations that serve low-literacy adults and families in the Hattiesburg community. This will enable the students to take this knowledge about adult learners and family literacy programs into their jobs as librarians. ... While my focus is on new librarians, I believe that it has the potential to provide a bridge between literacy programs and libraries, or adult educators and librarians. It would bring students from both areas together to work, which could positively affect the administration of adult literacy programs in both community centers and libraries.

The application essay reflected that JB was well aware that the goal of service-learning is not just to meet the needs of students and faculty but also to meet a community need:

Because Mississippi has lower-than-average literacy rates, our new librarians need to be aware of the needs of new readers and ways that they can work with other community agencies in order to coordinate literacy programs. It is especially compelling to bring students into the conversation, because it will expose them not only to theories, but hands-on work to positively affect their motivation to continue work in this important area. There are many well-established literacy programs throughout the state which could give our distance students ample ground to participate and make a difference in their own communities, as well... While public librarians might directly face problems related to adult literacy, they also might come to the job unprepared for such challenges. By challenging students to face this problem in the university setting, they will not be caught off-guard with this common problem, and will be equipped to form community partnerships to combat illiteracy through understanding. This course would enable them to learn about materials in the adult education classroom and how to organize adult and family literacy 
programs, using programs that are already in place in Hattiesburg as a learning laboratory.

An early reflection during the first weeks of the seminar reiterated the initial enthusiasm shown in the application, with the addition of a new goal brought about by the first readings: To break down barriers and stereotypes. "As one student noted when he became involved with a service-learning program, his previous "stereotypes were just destroyed." He had moved beyond friendship or identification with [the people he worked with] to reflection on the nature of the social structure" (Eyler \& Giles, 1999, p. 142). This quote prompted JB to write,

...I do think that when my students come in, though, they will be presented with a project that will engage them on many levels. They will be able to work with materials that they don't encounter in their own libraries, which will give them another tool in their librarian toolkit... The civic action portion of my program is to help break down social barriers between the students and future library patrons who might fall outside of their perceived norm.

Gallayanee Yaoyuneyong (GY), second year Assistant Professor of Fashion Merchandising in the Department of Management and Marketing

GY believed that the fellowship would not only open a window of opportunity for her students and herself but also for the university to be part of the community. She strongly believed that education, especially at the university level, should provide students with more than knowledge and theory and through this fellowship she hoped that she could help her students cultivate skills that working with a real community could give them. Before she applied for the fellowship, she heard the news about the dropout rate and the State Dropout Prevention Plan released by the Mississippi Department of Education. She decided that her students could be part of this prevention plan by partnering her class with an agency that helps with the dropout problem. She planned on integrating a service-learning component in the course titled Textiles. The following excerpt from her application reflected her hopes,

Since Hattiesburg is the home of USM, USM's faculty and staff should be considered to be a part of the Hattiesburg community...and scholastic body. When one part of the body hurts, all other parts suffer as well. Thus, it would be very beneficial if USM could work with the Hattiesburg Public School District (HPSD)...My students and young entrepreneurs would serve as role models for high school students by helping them recognize how high school and college graduation can lead them to a better life.... High school graduation is the first key for success. The windows of opportunity open even wider when a student graduates from college. If they try to follow their dreams, graduates can one day own their own businesses.

In her application, she expressed her expectations about her students' projects: Through the service-learning methods, I expect my students to better understand the class concepts as well as become more creative when coming up with a final project and presenting it to the younger students. Besides academic achievement, I want my students to 1) create a network with the Hattiesburg community, 2) gain contacts with local businesses, non-profit organizations, and academic leaders, 3) gain confidence before they graduate, 4) learn social responsibility through a service-learning project, and 5) learn that they can make an impact and be positive examples for other people. This experience will help my students realize their potential and find ways to achieve their dreams. I believe students should obtain not only academic knowledge through their college education, but also be equipped to be good citizens. 
As illustrated by our application essays and reflection pieces, we all sought to apply to the service-learning fellowship in order to provide our students with a level of learning that would surpass that of the traditional classroom. "If the task, in addition to learning content, is to excite and motivate students to learn during the course and after, to learn new ways of learning, and to develop a set of overall values in the field of study, then we know that the information-dissemination model is woefully lacking" (Howard, p. 61). Moreover, our enthusiasm entering the service-learning seminar mirrored our goals for our future students.

\section{Stage 2: Reality Check, or Facing Reality?}

Although we had very clear ideas of what we wanted to accomplish through service-learning and what we expected to gain from our participation in the ServiceLearning Fellows Program, we did not foresee how difficult the integration of the service-learning component in our classes would be and how our participation in the seminar would bring to light different issues that would make us doubt our initial ideas and the projects we had envisioned for our students. In this stage, our initial enthusiasm was replaced by self-doubt and fear as we began to realize that the ideal project that we had carefully thought out for our application might not be as easy to put into practice as we had believed. In this stage, three main themes emerged from our narratives: Finding a placement and meeting community needs, drafting the syllabus, and experiencing fears and ethical considerations.

\section{Finding a Placement and Meeting Community Needs}

One of the seminar's extensively discussed topics was the requirement that service-learning classes, and projects, must be focused on a real community need. "One of the most significant ways in which service learning differs from many other community-related campus-based initiatives lies in its insistence that the needs to be met must be defined by the community, not the campus" (Zlotkowski, 1999, p. 97). The first opportunity to put this into practice was finding a site for an individual service-learning project, the first assignment of the seminar. For this purpose, we were taken on a tour of some of the agencies by our seminar facilitator and the staff of the Office of Community Service-Learning. We were able to find our individual service-learning projects with relative ease.

CC) felt lucky when after visiting a number of agencies, she was approached to help with a real need:

I believed that the seminar would help me conceptualize and organize my ideas into a coherent and integrated project that would benefit the children in the community and my students. With that in mind and with the help of the Office of Community Service-Learning at the university I went out in search of my own individual service experience. I found my participant, G..., in a community after school program. I was asked to help this trilingual fifth grade to learn to read. G... is a speaker of Mixteco, Spanish, and English, but he could not read in any of his languages. I asked him if he would allow me to come and teach him to read and he said yes.

GY found her own service project during her visits, but it was different from what she had been looking for, "I have to be honest that volunteering at the Boys and Girls Club was not my original idea. I really wanted to do something that was closer to what I will require my students to do."

JB was presented with an individual project that fit perfectly with her service-learning course the second time she approached her community partner: They needed to reconstruct their lending library. She was able to begin the project by ordering library supplies and books; students in the fall would continue working on the project. However, she had also struggled with the idea of finding the right 
site for her students-would it be more helpful for the students to work in a library or a social service agency?

An early reflection demonstrated her relief when the project materialized: “Several weeks ago, I was afraid that I wasn't going to find a place for a project. Fortune managed to shine on me though and I seem to have been blessed with a bigger project than I might be able to complete-one that should bleed into next semester, hopefully with students at the helm."

For the other two of us, the process of identifying a place that would fit our project idea, would meet the needs of the community and the needs of future students, and would help us integrate the service-learning component in the syllabus for our classes occupied our thoughts. The intimidation we felt was linked to our perception that the success of our future class hinged on the project. The emphasis in service-learning on identifying a community need and not imposing an idea or agenda on the community weighed heavily on our mind. We learned how to find a site to conduct research as part of graduate work, but relinquishing our own idea in lieu of a community's need turned out to be difficult, as the following excerpts illustrate:

GY reflected:

I have to admit that I struggle with my thoughts and ideas of what service-learning is and how my volunteering experience affects my worldview, especially in the Hattiesburg area. In addition, through the reading assignments, I cannot help thinking about service-learning and my class, how I can create a class that will benefit my students and serve the needs of the community. I have explored several possible community sites for my class; nonetheless, I could not find anything that really matched what I had in mind. Since the Boys and Girls Club was not my original idea, I also explored other service-learning projects. I contacted CCJ worried: the high school as well as the Community Education Center.

I still haven't found the community that will allow my students to perform the kind of service that I envision for my course, and consequently I have not found the place where the members of the community and my students will be able to meet. The Family Education Center where I work with G... doesn't have enough Spanish-speaking children to allow a class of 15+ students to do the kind of service-learning project I have in mind. This worries me because one of the most important tenets of service-learning is that the service has to fill in a real community need, or in other words, the members of the community have to identify the need and then I can collaborate with them designing the best way to provide the service they need and integrate it into my course.

As GY's and CCJ's comments reflect, while in this stage, some faculty are forced to face the fact that the reality of the community situation may not match what they had first envisioned for their service-learning component and giving up their original idea might be difficult.

\section{The drafting of the syllabus}

All seminar participants felt that the seminar experience was extremely valuable in helping them conceptualize their plans. It created an atmosphere where they could discuss their ideas and problems with their syllabi. Additionally, it provided space for discussing practical issues and fears. It is not easy to transform a more traditional syllabus to a service-learning syllabus. It requires many practical considerations, which sometimes seem to get in the way of faculty member's civically-minded goals.

For GY, her main worry was the integration of the journaling and reflection components of the service-learning project and how to give her students relevant 
prompts so they could connect their readings with their experiential learning. She wrote:

I struggle a lot with the revision of my class. I try to find similar projects but I cannot find one. The syllabus revision is not difficult to do but the activities such as journaling or writing reflection papers that I will require my students to do are still very unclear to me (though I read about it in the literature). ...I am afraid that my students will not receive the full benefit from the project because of my incompetent writing of a guideline or requirements for journal and reflection papers.

CCJ struggled with the design of her course and the fit of the servicelearning component with the subject matter. She needed to connect both in her mind before she could write her syllabus, let alone think about journal prompts and reflection papers:

I am still working on the syllabus and the design of my course and wrestling with the seamless integration of the service-learning component with my Introduction to Literature class. At the beginning of our seminar I just couldn't see how a literature course could be conducive to integrating the kind of literacy work I wanted to do with the academic requirements of the course. I am still not over the worry of how home language literacy and the theory about teaching literature can fit together... If I don't know what the service-learning component of my course is going to be how can I think about the topics for my students' reflection papers?

JB wrote little about the seminar and revising the syllabus in her reflections, though she did discuss this with her peers in class. She reflected about how her own project would make her students' work possible in the class she was preparing: "[This project] is the ideal 'in' for my students next fall."

These comments show that, in this stage of transformation, faculty frustrations with course design are often in direct proportion with whether a site and/or a suitable project has emerged. JB, for instance, worried the least because from the second visit to her service project site she knew what her students were going to be doing in her service-learning course. CCJ, however, struggled the most with her course design and the drafting of the syllabus; by the end of the seminar she still had not found the specific Spanish speaking community for which she was looking.

\section{Fears and ethical considerations}

In addition to fears regarding the project's goals, our reflective writings also contained fears of personal failure and explorations of shortcomings regarding our own projects. More problematic, though, were the fears expressed regarding possible ethical problems with our work. These two types of fears were often intertwined in the authors' reflections.

GY expressed doubt that her project would be worthwhile for her students: "Deep down in my heart, I am afraid that my class service-learning project will not succeed. I am also afraid that all my work will be wasted." On the other hand, JB was frightened that she had taken on a project too substantial for her to handle:

I don't know how to do this-I've never worked with vendors, and she wants me to send her lists of books to order. I'm working with catalogs and websites, trying to figure out what is best, and I think I'm making some headway, but I don't know how she wants me to order the books!...I hope that I am not exposed as a fraud or as incompetent. She [the program director] also wants books that reflect the population that uses the center. I feel strange ordering 'black parenting' books, because I don't know if that is 
being presumptuous! I have found some good websites for black parenting, but since I'm not African-American I feel a bit like an impostor.

Some of the fears expressed were caused by the fact that in servicelearning students work with actual people, not abstract ideas that are presented in a textbook. In fact, imposing one's own research agenda is antithetical to the servicelearning concept. This topic kept coming up in seminar discussions, because junior faculty members, in particular, are pressured to write about their research. Putting so much time and effort into teaching, which does not count as heavily in one's tenure docket, was daunting. The seminar participants often

\author{
Some of the fears expressed \\ were caused by the fact \\ that, in service-learning, \\ students work with actual \\ people, not abstract ideas \\ that are presented in a \\ textbook.
} discussed this issue, reminding themselves that they could not impose an agenda on their service site even if they felt the pressure to produce publishable research at the conclusion of the service-learning experience.

JB described the issue in terms of feeling presumptuous: "I don't work there....It is difficult to know exactly what they need, to feel as if I'm helping them like I should be according to the principles of service-learning (to serve, not necessarily guide or impose). The nature of the project seems a bit presumptive, in that I am dictating what I think they need."

Because students will be dealing with real people, ethical considerations are a large issue. The community must be regarded as a partner, not a subject, and students must be sent into the community with the attitude of service to, not of taking from. CCJ said this well when she reported:

There are always ethical considerations when you bring change to a person's life. Before I started working with G..., I was sure that what I was going to do was the right thing for him, but after I got started I began to question the rightness of my thinking. I questioned who or what gave me the right to change G...'s world. How would he feel about his family after he learned to read? How would his reading ability affect his relationships? Would this skill bring him happiness or unhappiness? teaching: After she started working with " $G$ "... she began to worry about her actual

I also questioned my approach to teaching him to read. I had used a Spanish first and English second approach with my own bilingual children, and it had worked extremely well. Once they learned to read in Spanish, they simply transferred that skill to English. But is this the correct approach with G...?

J $B$ restated her feelings of inadequacy, emphasizing the lack of control when dealing with social situations:

I think that one of the problems that my students will experience that is similar to my own is the feeling of incompetence or of feeling as if we lack control over the project. Service-learning requires the participant to do work for someone else, and in this situation we might not know as much as we would like to know about the people who we are working with.

The common threads above show that, just as we learned in class, "transforming a classroom from a traditional orientation to one that is consistent with the goals and opportunities associated with academic service learning is not easy" (Howard, 1998, p. 24). We agree here with Howard: "[A]cademic service learning is not for the meek" (p. 25). Our experiences exemplify that "reformatting classroom norms, roles, and outcomes so that both academic and experiential learning can be joined requires a very deliberate effort around a rather formidable challenge." (p. 25). Howard also described service-learning as a "counternormative pedagogy" and added that 
"instructors who accept this challenge can expect...periodic self-doubt about their own teaching accomplishments" (p. 25). We concur with him, but we propose that the self-doubt appears earlier, much before any teaching is actually done, while learning about service-learning and designing a course that will allow the inclusion of service as an integral part of the students' learning.

\section{Stage 3: Recommitment to Service-Learning}

After conquering our doubts and fears we found that at the end of our participation in the seminar, our initial ideas had changed in ways that we had not anticipated. At the same time, we found a renewed commitment to service-learning pedagogy, not just with the purpose of integrating a service-learning component into our classes, but as a way of learning about the scholarship of teaching and belonging to an interdisciplinary collaborative entity. The following threads are taken from later reflections and journal entries.

JB pointed out that one outcome of the seminar was a clear sense that her teaching should continually evolve:

Another great thing about the seminar was that the teachers who came in discussed their own failures-that teaching isn't always smooth going, and that their courses required a lot of revisions before they really worked. They were invited to talk at the seminar because they have been successful; so even though some of their classes didn't work out as well as they had hoped, they were still regarded as competent by their peers.

CCJ expressed gratitude for the seminar:

Through my participation in the seminar I have been able to overcome my first obvious fear: how a literature course could be conducive to integrating the kind of literacy work I wanted to do with the academic requirements of the course. Zlotkowski (2003) gave me the change of perspective I needed. He makes clear that the purpose of service-learning assignments is not just to improve the technical, discipline-specific effectiveness of student skills, but "to gain... a broader appreciation of the discipline, and an enhanced sense of civic responsibility" ( $p$. 222). I realize now that my students will be gaining "a broader appreciation" of their chosen discipline, Spanish, by putting their skills with Spanish to the service of the community.

After reading Zlotkowski's article, CCJ began the process of relinquishing her initial ideas and opening her mind to other service-learning experiences for her students. For CCJ, giving up her own idea of what she had envisioned the community needed was very difficult, but by the end of the seminar she was able to somewhat let go of her own plans and had started to look at other possibilities:

Even though at the beginning of the seminar I was set on working only with children; my work with G... has made me realize that there is probably just as great of a need for literacy among the Spanish speaking adult community. I am thinking now, that if I cannot find a community need for literacy in Spanish, I might find a community need for sharing the Spanish language and its cultures among children who do not have the chance of learning a foreign language in their school. I feel that my students and I can 
provide the two sides of the same coin-language literacy in Spanish-for those that do not read or need to read more in their home language and for those that want to learn another language.

She finally seemed reconciled to the new avenues that might open up for her students, and expressed a renewed commitment to service-learning as a pedagogy that would benefit her students and where they might serve: "The service-learning component for my course might not be exactly what I first envisioned and what brought me to this seminar, but I know that ultimately it will be of value both to the community and to my students."

JB was still facing some issues with her own project at the end of the seminar; while others' individual projects had ended, hers was picking up, and she found that she did not have enough time to devote to it because of other academic commitments. However, she was hopeful that things would continue to progress slowly over the summer so that the agency wouldn't think she is shirking her duties. The following expressed some doubts, but ultimately reflected her optimism: "I think that if everything pans out with my work over the summer, my students will be prepared to take on a great project this fall. The project isn't as ambitious as I had originally envisioned; the students will have to learn most of the theory from their readings, which is really what is supposed to happen anyway."

The following from GY demonstrated faith in the pedagogy, even though she was still overwhelmed by the amount of work that service-learning required:

Now that I have found out what the community needs and what projects will be appropriate to my class, I encounter new challenges. It seems like there are many hills I need to climb. I also believe that once I succeed in conquering this mountain, I will find another hill on the other side. Although I feel frustrated sometimes, the benefits that my students will receive from the project keep me going.

She continued, bringing up the concept of self-realization:

The experience gained from the service-learning project will be unique but sort of similar in the big pool. In addition, through my own service-learning project, I have come to understand myself better. This experience combined with class knowledge will become real in the students life in a similar way to what servicelearning has become to mine. Community will be part of their life regardless of where they are.

GY summarized well all of our feelings regarding the value of our service-learning experience:

Since I have received so much from my own experience with the service-learning project and seminar, I would love for my students to benefit from this and I want to apply a service-learning learning component in my classes. I totally believe that service-learning is a powerful teaching tool to teach more than class subject matter to students.

Our reflections in this stage showed that despite the unforeseen difficulties we encountered in the process of learning about service-learning pedagogy and integrating it into our courses and syllabi, we are definitely committed to the pedagogy. All three of us will be teaching our service-learning course in the coming semester, putting into practice what we learned during the seminar and our own service projects.

\section{Conclusions}

Service-learning is one way to actively involve faculty in the scholarship of teaching; seminars such as the one at USM in faculty development are valuable for faculty engagement and continued educational development and growth, and for engaging faculty in the scholarship of teaching toward transforming their pedagogies. As Zlotkowski (1999) pointed out, "regardless of the individual choices 
individual faculty make with regard to the educational rationale, the kind of community service, and the course format, service learning requires instructors - no less than their students - to become 'reflective practitioners' (Schon, 1983, 1987)" (p.102).

It is important to realize that the process of integrating a service-learning component into a class is a very involved task that includes a lot of thinking and reflection, giving up ideas, and being flexible. For us, the process evolved from the initial ideal plan to a realistic look at what can be done, through

It is important for universities to provide forums for faculty development outside of the narrowness of departmental boundaries.

three clear stages that evolve from the initial enthusiasm, through self-doubt and fears, to a realistic renewed commitment to the pedagogy.

It is important for universities to provide forums for faculty development outside of the narrowness of departmental boundaries. The involvement in this seminar has allowed faculty from different disciplines who normally would not work together to do so, and to feel connected to a campus-wide movement, bringing them out of the insularity of their own departments to a feeling of belonging to a community that transcends their chosen disciplines, personal objectives and goals. We feel that we truly have become part of a community of "reflective practitioners," actively engaged in the scholarship of teaching. This is a real example of the transformative power that service-learning has not only in student learning but also in faculty learning and teaching.

\section{Limitations of the Study and Questions for Further Research}

Even though this study is limited to the personal experiences of three faculty members, it shows that service-learning has a major effect on the faculty who decide to adopt this pedagogy. Further research involving more faculty is needed to expand on the ideas proposed in this article:

- Does the three-stage process of faculty transformation that emerged in this study occur in other seminars on course redesign?

Other possible topics for research on faculty in service-learning are the relationship that service-learning faculty have with their institution, and its effect on job satisfaction. Some specific questions we have are:

- Do faculty that engage in service-learning develop stronger crossdepartmental relationships with other faculty than those that are not involved in it?

- Does institutional support for service-learning faculty improve the degree of satisfaction of the faculty with the institution?

- Does service-learning have an effect on junior faculty retention and tenure and/or promotion?

We welcome your questions or comments regarding service-learning in general or on this particular study.

1 The hyphenated term "service-learning" will be used by the authors throughout this paper, except in direct quotes where the hyphen has not been used. See Eyler and Giles discussion on Where is the Learning on Service-Learning (pp. 2-5).

2 The table is being used with permission of Trigwell et al. The authors of this paper added the level column for clarification.

${ }^{3}$ See Appendix A

${ }^{4}$ This comment is not meant as criticism. Since the main goal of service-learning is student learning, it is not surprising that most research has focused on student outcomes. The authors realize how important is all the research done in this area. 


\section{References}

Braid, D. (1996, Winter). Personal narrative and experiential meaning. The Journal of American Folklore, 109(431), 5-30.

Campus Compact. (2003). Campus Compact's introduction to servicelearning toolkit ( $2^{\text {nd }}$ ed.). Providence, RI: Brown University.

Dewey, J. (1916). Democracy and education. An introduction to the philosophy of education (1966 ed.) New York: Free Press.

Eyler J., \& Giles, D. E. (1999). Where's the learning in servicelearning? San Francisco, CA: JosseyBass, Inc.

Eyler, J. S., Giles, D. E., Stenson, C. M., \& Gray, C. J. (2003). At a glance: what we know about the effects of service-learning on college students, faculty, institutions, and communities, 1993-2000. In Campus Compact (Ed.), Campus Compact's Introduction to Service-Learning Toolkit Readings and Resources for Faculty ( $2^{\text {nd }}$ ed., pp. 15-19).

Providence, RI: Brown University.
Furco, A. (1996). Service-Learning: A balanced approach to experiential education. In B. Taylor (Ed.), Expanding Boundaries: Service and Learning (pp. 2-6). Washington, DC: Corporation for National Service.

Howard, P. F. J. (1998). Academic service learning: A counternormative pedagogy. New Directions for Teaching and Learning, 1998(73), 21-29.

Schön, D. A. (1995, November/December). The new scholarship requires a new epistemology. Change, 27-34.

Shulman, L. S. (1993,

November/December). Teaching as community property. Change, 6-7.

Trigwell, K., Martin, E., Benjamin, J., \& Prosser, M. (2000). Scholarship of teaching: A model. Higher Education Research \& Development, 19(2), 157-168.

Zlotkowski, E. (1999). Pedagogy and engagement. In Bringle et al. (Ed.), Colleges and Universities as Citizens, (pp. 96-120). Boston: Allyn \& Bacon.

Carmen Carracelas-Juncal obtained her Bachelor's and Master's degrees at Brigham Young University, and her PhD in Hispanic Linguistics and Literatures at the University of Massachusetts at Amherst. She taught at Amherst College and the School for International Training Graduate Program before joining the Foreign Languages and Literatures Department at the University of Southern Mississippi.

Jenny Bossaller graduated from the University of Missouri with a Master's degree (2002) and a PhD (2008) in Library Science. She teaches in the School of Library and Information Science at the University of Southern Mississippi.

Gallayanee Yaoyuneyong is originally from Bangkok, Thailand, where she earned her Bachelor degree. She graduated from Eastern Michigan with a Master's degree (2004) in Human, Environmental, Consumer Resources, emphasis in Apparel, Textiles, and Merchandising, and received a Ph.D. (2007) in Human Sciences, emphasis in Apparel/Textile Product Development from Florida State University. Currently, she teaches in the Department of Marketing and Fashion Merchandising, College of Business, at the University of Southern Mississippi. 
Appendix A: Academic Service-Learning Faculty Fellow Application

\author{
OFFICE OF COMMUNITY \\ SERVICE LEARNING \\ The University of Southern Mississippi \\ Division of Student Affairs \\ Box 10031 \\ Hattiesburg, MS 39406 \\ E-mail: david.brooking@usm.edu \\ www.usm.edu/ocsl \\ Phone: (601) 266-5074; Fax: (601) 266-5870
}

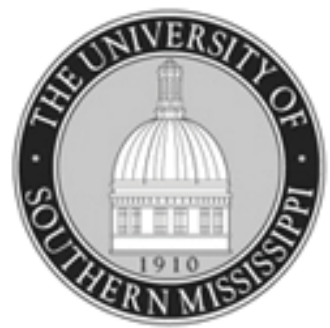

The Office of Community Service Learning will select 6 faculty members to participate in the Service-Learning Faculty Fellows Program for the spring 2009 semester. Each of the 6 faculty selected will receive one course reassigned time for the semester in which they participate in the service-learning seminar. Departments will be reimbursed for a faculty member's time. This service-learning fellowship is made possible by the generosity of the Provost's Office and the Vice President for Student Affairs.

\title{
Expectations:
}

- Attend a weekly ( 2 hour) seminar focusing on topics such as course design, social responsibilities of universities, liability, assessment, and reflection as they relate to service-learning courses.

- Modify an existing course to include academic service-learning.

- Commit to teach a service-learning course in the following academic year.

\section{Selection Process:}

Service-Learning Fellowships are open to full-time USM faculty members at the rank of instructor and above. We seek faculty representing a variety of disciplines and areas of expertise, and with varying degrees of familiarity and experience with service-learning. Preference will be given to those faculty members who articulate a clear vision of how service-learning fits into their professional development as teacher-scholars. Selections will be made by the Faculty Fellows Advisory Council and the Office of Community Service Learning.

Application:

Service-learning is a method of experiential education in which students learn and develop through active participation in and reflection on thoughtfully organized community service experiences tied to an academic course.

1. Have you used academic service-learning in the past? If you answer yes, please list some examples of your activities.

2. I am interested in adapting the following course(s) to include servicelearning:

3. Please attach a current syllabus of the course you think you might revise for a service-learning component.

4. What is the potential of your discipline for application within the Hattiesburg community?

5. What is the possibility for publication or research as a result of your service-learning work?

6. How will this fellowship (a) complement your professional development plans and (b) contribute to your students' academic development? 